Article

\title{
Living Compound Marginality: Experiences of a Japanese Muslim Woman
}

\section{Kieko Obuse}

Institute for Foreign Studies, Kobe City University of Foreign Studies, Kobe, Hyogo 651-2187, Japan;

kieko.obuse@regents.oxon.org

Received: 29 March 2019; Accepted: 13 July 2019; Published: 16 July 2019

\begin{abstract}
The present article discusses the ways in which ethnic Japanese Muslim women are perceived and treated in contemporary Japanese society, through a case study of one Japanese female convert. It examines the complexity found in her experiences of marginality by highlighting three inter-related modes of marginalization: marginality deriving from being a Muslim, from being a Japanese Muslim and from being a woman. It discusses her responses to these discourses of marginalization and how she establishes her identity as a Muslim, through responding to them. The article first shows that ethnic Japanese Muslims suffer 'inverted marginality' - marginalization due to belonging to the ethno-cultural majority. It then demonstrates their experience of 'double marginality', marginalization by the wider Japanese society and foreign-born Muslims alike. It argues that their experience of double marginality has partly resulted from the absence of a self-sufficient ethnic community of Japanese Muslims. Ethnic Japanese Muslim women experience further marginalization when they become targets for criticism of Islam, such as that Islam is a religion of female subjugation-a notion of gender orientalism that deprives these women of their agency. However, the process of responding to these challenges of marginality helps ethnic Japanese Muslim women consolidate their identity as Muslims.
\end{abstract}

Keywords: Islam; marginality; women; Japan; conversion; identity; minority; ethnicity; gender

\section{Introduction}

For many Japanese living in the second decade of the twenty-first century, it is no news that there is a small Muslim community in Japan. The number of mosques has been on a steady increase, with encounters with foreign-born Muslim residents becoming more common in big cities. Particularly notable is the recent rise in the number of tourists visiting Japan from Southeast Asia, such as those from Indonesia and Malaysia. This has led the tourist and hospitality industries to market halal food and to create prayer rooms in such places as major train stations and shopping malls. The rapidly increasing attention paid to the so-called halal business has also boosted the demand for halal certifications, with various certification bodies operating within the country. ${ }^{1}$ Given these developments, one may be inclined to say that awareness of Islam and Muslims among the Japanese is gradually improving. However, the increased level of focus on dealing with Muslim tourists from overseas can also reinforce the common Japanese perception of Islam as a foreign religion, further reinforcing perceptions of Muslims as cultural Others. While it is true that Islam is not indigenous to Japan and that the majority of Muslims living in Japan have foreign origins, the idea of Muslims being foreigners or Islam as a foreign religion (or culture), can entail a risk of making ethnic Japanese Muslims living in Japan

1 For more on the halal businesses and issues concerning halal certification, see, for example, (Fujita 2017; Numajiri 2017; Yagi 2015, p.89f) 
invisible and their lived experiences difficult to understand. As will be shown below, one major factor in their marginalization in contemporary Japanese society stems from the very fact that they are Japanese, that is, they belong to the majority ethno-cultural group. ${ }^{2}$

The present article explores the ways in which ethnic Japanese Muslim women experience their marginality in contemporary Japanese society and how they construct their identities in response to such experiences, through a case study of one Japanese female convert to Islam, Naoko Kawada (1957-). It argues that there are three main inter-locked modes of marginalization in operation in her lived experiences; firstly, marginality deriving from being a Muslim; secondly, that deriving from being Japanese, that is, not being a foreigner; and lastly that deriving from being a woman. It examines how these differing modes of marginality are built upon each other, constituting a 'compound marginality'. It explores her response to these discourses of marginalization and how she establishes her identity as a Muslim, through responding to them. The present study is proposed as first step to constructing an analytical framework for the marginality experienced by ethnic Japanese Muslim women, on the basis of which the experiences of other ethnic Japanese Muslims and potentially those of converts to Islam in other non-Muslim-majority societies, can be analyzed, taking account of their differing social contexts.

The present study is mainly based on the interviews I conducted with Kawada from 2018 to early 2019 in the Kansai area, where she plays a leading role among ethnic Japanese Muslim women. ${ }^{3}$ The discussion of her experiences also draws on her publications and newspaper articles that feature her. In discussing the situations surrounding ethnic Japanese Muslims in general, reference is also made to the information obtained through the previous fieldwork (participant observations at mosques and interviews) I conducted on the activities of ethnic Japanese Muslims in 2014 and publications by and about ethnic Japanese Muslims, including those on Internet sites. Additional information on Kawada's experiences has also been obtained through my personal communications with her.

Before proceeding, a note of clarification on Kawada's stance towards the present project is in order, which reflects the complexity of the life as a Japanese Muslim woman. I met Kawada through a female academic friend. It was after we were acquainted personally that I came up with the idea of the present study. In not being a Muslim, I am an outsider to Kawada. This seems to have been an advantage in the present context; indeed, she says she is generally more comfortable socializing among non-Muslim friends, as she does not need to worry about being criticized for what she says or does by other Muslims (meeting, July 2018; meeting, March 2019). Most of the interviews were conducted in the presence of the friend who introduced me to Kawada. She willingly shared her experiences with and feelings about Japanese society, Japanese women, foreign-born Muslims as well as fellow ethnic Japanese Muslims, only asking me to keep one episode 'off the record.' However, it is important not to exclude the possibility that she soft-pedalled on her criticism of Japanese society or Japanese women due to being in the presence of two non-Muslim Japanese women.

It is furthermore essential to note that Kawada was initially reluctant to be interviewed due to the disappointing experiences she had had with the media and for fear of the reaction and potential backlash from fellow Japanese Muslims. She only agreed to cooperate upon hearing that it would be published in English and that it would include an analysis of her main concerns (meeting, August 2018). This included consent to be quoted unanonymized. Although she is aware that the article may be read by Japanese Muslims, Kawada does not regard this as problematic. 'Those who read academic articles in English will be scholars [who are unlikely to criticize my stance]. Even if they do comment, it

2 The present discussion refers to Muslims residing in Japan as 'foreign-born' or 'ethnic Japanese' to highlight the fact that the ways in which they are perceived and marginalized depend on ethnicity rather than nationality. See Section 3 for elaboration on this point.

3 I conducted two long interviews with her in October 2018 and January 2019, both consisting of two sessions. These are referred to as 'interview, October 2018' and 'interview, January 2019' respectively. Small exchanges we had in between the interview sessions are treated as forming part of the day's interview. I also draw on personal conversations we had in July and August 2018 and March 2019, which are referred to as 'meeting, July 2018', 'meeting, August 2018', and 'meeting, March $2019^{\prime}$ respectively. 
will not lead to serious trouble (personal communication, April 2019).' She also makes it clear that she does not mind receiving critical comments and will be willing to respond to them. 'That's why I spoke about many things, for example, in my interviews with newspapers but why do they publish just that! (ibid.)' The last comment reflects her frustration at the media's tendency to focus on the issues of women and halal food and to disregard issues that are of more importance to her. ${ }^{4}$ During the process of writing the present article, I kept her informed of my progress and asked her for clarifications when necessary. She has read the draft version of the article and agreed to its publication.

\section{The Compound Marginality of Ethnic Japanese Muslims}

The number of Muslims residing in Japan is not officially established but is estimated at around one hundred forty to one hundred fifty thousand. The majority are migrant Muslims originally from countries such as Indonesia, Pakistan and Bangladesh and their children (Okai 2018, pp. 25-26). Twenty to thirty thousand are considered to be ethnic Japanese Muslims, a minority among a minority. While many of the ethnic Japanese Muslims converted to Islam upon marrying a foreign-born Muslim, there are also those who embraced Islam out of their own conviction. The children of the ethnic Japanese converts are born and brought up as Muslim, constituting the second generation of Japanese Muslims (Okai ibid., pp. 26-27). ${ }^{5}$

It has been pointed out that Japan's Muslim community is like a collection of communities rather than one single community in that it is comprised of many communities of different linguistic and cultural backgrounds (Sakurai 2008, p. 70, 86, p. 71; Kawada 2004, p. 182). Such communities tend to be formed around mosques, with halal shops and restaurants located nearby. However, this tendency does not apply to ethnic Japanese Muslims, especially those who do not have family ties with foreign-born Muslims. ${ }^{6}$ Due to their extremely small number, they do not usually have their own 'ethnic' mosque communities where they reside. ${ }^{7}$ This means that ethnic Japanese Muslims usually have to operate within a community (or communities) where the majority of community members are of foreign origins. ${ }^{8}$ As will be shown, such lack of ethnic independence may partly be behind the marginalization of ethnic Japanese Muslims within Japan's Muslim community.

The existing scholarship on Muslims living in Japan has tended to deal with migrant Muslims and female Japanese converts who are married to non-Japanese Muslim men. Recently published research covers such topics as the networks of migrant Muslims seeking employment or setting up businesses in Japan (Higuchi et al. 2007), the process of identity-building of Japanese women married to Pakistani Muslim men (Kudo 2008), the development of mosque-based communities (Tanada 2015) and the expansion of halal businesses (Numajiri 2017). ${ }^{9}$ A similar focus is found in the media coverage of Japan's Muslim community, with common topics including the development and activities of migrant Muslim communities and their relationship with local Japanese communities, stories of couples or families involving a migrant Muslim and a Japanese spouse, as well as the increase of halal businesses

4 See Section 4 for her experiences with the media. The fact that she preferred not to have her opinions published in Japanese, that is, through the medium easily accessible to Japanese Muslims, suggests that she has been placed in awkward situations vis-à-vis ethnic Japanese Muslims by voicing her views publicly, although she did not give examples during the interviews. It is only certain that it was not through publishing her 2004 book, which she does not regret having published and for which she received some positive feedback (interview, January 2019).

5 For more on the demography of Muslims living in Japan, see (Tanada 2015, chapter 1).

6 It has to be noted that some ethnic Japanese Muslims are involved in the management of a mosque, playing a leadership role in the mosque community. For more on mosque management, see, for example, (Tanada 2015).

7 The Japan Muslim Association, which is run by and for ethnic Japanese Muslims, has in some sense served as an umbrella organization for ethnic Japanese Muslims, yet it is impossible for one single organization to cater for the day-to-day needs of Japanese Muslims across the country.

8 The sense of alienation they feel in mosques where foreign-born Muslims form groups in accordance with their ethnic backgrounds is noted by Kawada and one other Japanese Muslim woman (interview, October 2018). To address this lack of a mosque-based ethnic Japanese community, initiatives have been taken to set up various activity groups among Japanese Muslims, especially Japanese Muslim women (Kawada 2004, p. 183; 2011, pp. 35-44).

9 For a list of major publications on Islam in Japan, see (Obuse 2015). 
and how schools deal with the increasing demand to cater for the needs of Muslim children. As part of this last topic, coverage of the experiences of Muslim children is also emerging. ${ }^{10}$ Themes concerning two common perceptions of Islam, namely, that Islam is an intolerant religion that is prone to violence and that it discriminates against women, are often taken up and Muslims' responses to these views explored. ${ }^{11}$

As pointed out above, the focus on foreign-born Muslims and their families in the media and academic works makes the presence of ethnic Japanese Muslims who do not have family ties with foreign-born Muslims rather invisible. While a number of autobiographical works and introductory books on Islam authored by ethnic Japanese Muslims have become available in the past two decades (Suzuki 2002; Kawada 2004; Higuchi 2007; Nakata 2015), detailed discussions of the experiences of ethnic Japanese Muslims are still relatively rare. Most of the works on ethnic Japanese Muslims published in the first decade of this century focus on ethnic Japanese women who are married to foreign-born Muslim men (Kudo 2007, 2008, 2009, 2014; Terada 2003; Takeshita 2001). Isurāmu to Nihonjin [Islam and the Japanese] (Iimori 2011) features contributions by senior and leading figures of the ethnic Japanese Muslim community, covering topics such as their experiences of the Islamic world, the development of the Japanese Muslim community, life as a Muslim in Japanese society, the first generation of ethnic Japanese converts and ethnic Japanese Muslims' efforts at interfaith dialogue with Japanese religions. However, they do not involve a discussion of the current situations surrounding ethnic Japanese Muslims.

It is only in recent years that a few books have been published focusing primarily on the experiences of ethnic Japanese Muslims, both men and women, in contemporary Japanese society. Nihon no naka de Isuramukyo o Shinjiru [Embracing Islam in Japan] (Sato 2015) is a reportage that thoughtfully presents episodes from the everyday lives of Muslims in Japan, mostly ethnic Japanese Muslims. While it is rich in detail and contains some useful comments, it does not provide a systematic analysis of the positions of ethnic Japanese Muslims in Japanese society as a whole. Nihon to Isurāmu ga Deau Toki: Sono Rekishi to Kanōsei [When Japan Meets Islam: the History and Possibility [of their Coexistence]] (Komura 2015) devotes two chapters to examining different ways in which ethnic Japanese people convert to Islam and develop their own modes of practice (Komura 2015, chapters 5 and 6). The author notes that ethnic Japanese Muslims are less likely to be accepted than foreign-born Muslims in wider Japanese society, ${ }^{12}$ and acutely observes that this can be attributed to the Japanese tendency to view being Muslim and being Japanese as exclusive categories (ibid., pp. 153-59). As will be discussed in more detail below, to become a Muslim, in the view of many Japanese, is tantamount to becoming a foreigner, although ethnic Japanese converts are still expected to conform to Japanese social norms. An understanding of the lived experiences of ethnic Japanese Muslims, especially women, requires an examination not just of expectations based on ethno-cultural distinction. Many of the cases discussed in the work are of women who face challenges such as the wider Japanese society lacking the understanding for the practice of wearing headscarves (ibid., p. 126) and have foreign-born spouses who obstruct their wives obtaining detailed knowledge about Islam (ibid., pp. 135-37). However, Komura does not discuss how the factor of gender influences the ways in which those women experience their marginality. As will be shown below, ethnic Japanese Muslim women's experiences differ from those of ethnic Japanese Muslim men in significant ways, making gender a significant factor in the marginality of ethnic Japanese Muslim women.

10 For example, see (Sato 2010a, 2010b; NHK Educational TV 2016). The latter is an episode of a TV program on education of school-age children. The episode discusses the experiences and perspectives of Muslim parents and children, featuring both foreign-born and ethnic Japanese parents.

11 This tendency is clearly seen, for example, in the series of six articles published by Nippon.com (Kono 2017a, 2017b, 2017c, 2017d; Kunifuda 2017; Yamaguchi 2018), where the first and fifth segments deal with the question of terrorism and women respectively. For more on the media's focus on the position of women in Islam, see Section 4.

12 This has also been pointed out in (Sato 2015, pp. 67, 206-7; Kawada 2004, p. 179). 
The marginality experienced by ethnic Japanese Muslims is a product of different modes of marginality building on each other. For ethnic Japanese Muslim women, three main sources of marginality can be highlighted as underlying the structure of their 'compound marginality,' namely, being a Muslim, being Japanese and being a woman. These multiple modes of marginality are not experienced separately but in a compound form. They are like three layers of watercolor which, when painted on top of each other, merge to produce different tints and nuances, adding to the overall strength of the color. What follows examines how the compound effect of multiple modes of marginality manifests itself and is experienced and responded to by ethnic Japanese Muslim women, utilizing the case study of a female ethnic Japanese convert to Islam.

In the present study, the term marginality is employed in two inter-related meanings. Firstly, it refers to a situation in which an individual or a group has come to inhabit two distinctive cultural spheres that are generally perceived to be conflicting, a condition sometimes described as being 'between cultures (Bourque 2006, p. 245).' This draws on the concept of marginality based on Robert Park's 'marginal man (Park 1928), ' characterized with 'contact and collision' of cultures (Goldberg 2012, p. 201) in the experiences of migrants. Applied to the experiences of converts to Islam in a society where Islam is a minority religion, marginality refers to their hyphenated identity, namely, being Muslim and having an ethno-cultural background of the mainstream society and the resulting challenge of identity negotiation. The second way in which converts examined in the present study are 'marginal' rests on the fact that they experience negative effects of othering, which can take the form of being pressurized to conform to the mainstream social practice. As demonstrated below, this can be due to their religion, ethnicity and gender. This does not imply a collective social exclusion or economic disadvantage, which the concept of marginality is often associated with (Bernt and Colini 2013 , p. 14). No such phenomena have been observed in contemporary Japan with regards to ethnic Japanese Muslims yet, although Muslim women wearing a headscarf can be disadvantaged in terms of employment (Sato 2015, p. 67). Rather, the marginality of these women on this level lies in their perception that their aspirations and concerns are misunderstood, disregarded or belittled.

The present study is conceived broadly as a project in religious conversion. Following the recent scholarship, it views conversion as an ongoing process (e.g., Rambo 1993; Gooren 2010; Roald 2012) rather than as a singular event, for example, a conversion ceremony (or shahäda, profession of faith, in the case of Islam). It is a continuous process of meaning-making and identity-negotiation, where converts make sense of their newly adopted faith in the socio-political and cultural contexts in which they operate. Such processes of identity negotiation among converts to Islam in societies where Islam is a minority religion have been fairly well documented in European contexts (e.g., Zebiri 2008; Roald 2004). It is a continuous process of social interaction in that converts negotiate what it means to be a Muslim through interaction with other Muslims and with the wider non-Muslim society (Bourque 2006, p. 239). Regarding Kawada's experience as such a post-conversion socialization process, the following case study examines how she establishes her identity as Muslim through interacting with other Muslims, both foreign-born and ethnic Japanese and the non-Muslim Japanese.

The present study thus also forms part of the broader scholarship on the experiences of Muslim minorities, especially those of Muslim women, which have been a keen object of study of late especially in European contexts. It has been widely observed that the most widespread and most controversial issues concerning Islam that Muslims have to deal with today include violent extremism and oppression of women, which is often associated with the female practice of wearing headscarves. For example, Muslims are constantly asked to denounce violent extremism; if they do not, then they will be assumed to support it (van Es 2018, 2019b). The headscarf, on the other hand, tends to be regarded as the symbol of the purported backwardness of Islam (van Es 2019a; Allievi 2006, p. 120). It is a thorny issue that can divide not only Muslims and non-Muslims but also the Muslim community, that is, over what is permissible (halal) and not permissible (haram) in Islam (Allievi 2006). As is shown in the following, these trends are also very much part of the experience of ethnic Japanese Muslims, although the situations surrounding ethnic Japanese Muslims can differ from those surrounding European 
converts to Islam, as the history of collective Muslim presence is shorter and the Muslim presence less pronounced in Japanese society than in many European countries. The present discussion thus highlights major continuities and discontinuities between the experiences of Japanese and European converts where applicable. Through its focus on Japan, an area that still has not received sufficient attention, it contributes to the growing body of scholarship on the experiences of Muslim minorities, especially the ways in which converts negotiate their identities vis-à-vis the mainstream society and culture.

Naoko Kawada has a religious background that is fairly typical of a Japanese person. She is from a Buddhist family. Her family followed the Shingon school of Buddhism, while her maternal grandmother was a keen practitioner of Nichiren Buddhism. However, she did not grow up to develop a particularly Buddhist identity. She was also familiar with practices associated with Shinto, though, again 'without having an identity of being an ujiko of a particular shrine' (Kawada 2004, p. 25). She attended a Catholic kindergarten where she said the Lord's Prayer every morning (Kawada 2004, p. 15) and later studied history at Kwansei Gakuin University, a Christian institution. Her exposure to Christianity, though it aroused some interest, did not lead to serious involvement with the faith. While she was a graduate student, she started to work for Motoko Katakura (1937-2013), an anthropologist of the Islamic world, known especially for her works on Arabia. In 1996, she took up a free course of Arabic lessons provided by the Kobe Muslim Mosque (meeting, March 2019), the oldest surviving mosque in Japan, which was established in 1935. The immediate cause of her decision to convert was the last verse of the Qur'an that her Arabic teacher recited during one lesson. When she heard it, 'something special happened ... something inexplicable ... I was pierced with conviction that this was the truth' (Kawada 2004, pp. 53-55). About a year later, at the age of forty, she formally converted to Islam at the same mosque, acquiring the Muslim name Yasmin.

Kawada has been playing a leading role among ethnic Japanese Muslims. She has, for example, established a self-help group for ethnic Japanese women, organizing study sessions and teaching basic Arabic to new converts. She is also one of the few Japanese Muslim women who have book-length publications in her name and who has been interviewed by mainstream media. Her first publication, Nihonjin Josei Shinto ga Kataru Isurāmu An-nai [An introduction to Islam by a Female Japanese Believer] (Kawada 2004), is an introductory book on Islam, written in an accessible style, which draws on her personal experiences of becoming and living as a Muslim in Japan. She also edited a volume entitled Isurāmu to Josei [Islam and Women] (Kawada 2011), which brings together contributions by ethnic Japanese Muslims, both men and women, on topics concerning the activities of Japanese Muslim women, experiences of Japanese Muslim families and Islamic teachings on women. Kawada contributed a chapter on the acquisition of Islamic knowledge by ethnic Japanese women. While she is by no means typical of an ethnic Japanese Muslim woman, Kawada's involvement with publishing and the media makes a case study of her experiences highly valuable. This is because the processes she has experienced, of book-publishing and media-report on the theme of Islam and Muslims, reflect how Muslims, especially ethnic Japanese Muslims, are perceived and treated in Japanese society on the whole.

In discussing her conversion, Kawada emphasizes how she has always been 'an ordinary Japanese,' who 'never grappled with a deep philosophical problem or experienced great hardship in life' (Kawada 2004 , p. 2). Even when she was engaged in research activities regarding the Islamic world, she was never particularly interested in Islam (ibid.). When she started having Arabic lessons, she was determined to fortify her knowledge of Buddhism so that she could properly represent it when her Egyptian teacher asked questions about it (interview, October 2018). For the present examination of her experiences as an ethnic Japanese Muslim woman living in Japan, it is significant that her conversion was not due to a sense of discomfort or alienation in her native society; nor was it the result of a spiritual quest or a philosophical conundrum. She was comfortably a member of the cultural majority. She holds the conviction that 'Islam provides the same set of moral teachings and values as those she 
had been taught, only more convincingly' (Kawada 2004, p. 3). ${ }^{13}$ After her conversion, she began to experience members of Japanese society regarding her suspiciously. The ways in which she became a marginal presence in Japanese society, despite having no intention to alienate herself from dominant cultural or social norms, help identify discourses underlying the marginalization of ethnic Japanese Muslim women.

While the experiences of marginality discussed in the following may be shared by other ethnic Japanese Muslim women, the case presently examined can by no means be universally representative. First of all, Kawada's experiences may differ from those of many Japanese converts to Islam in that she converted to Islam later in life. While there is no comprehensive data available on the ages of ethnic Japanese Muslims when they converted to Islam, most of the Japanese Muslims I have encountered in person and in written sources converted in their twenties, with some converting whilst still in their teens (e.g., Terada 2003, pp. 136-37). Kawada's case is also atypical in that she is not married to a foreign-born Muslim. However, such cases are becoming more common, making them an important group worth analyzing. Kawada's situation is further rendered unusual by the fact that her spouse, who is ethnic Japanese, is not Muslim; she was already married when she converted. As far as her narrative is concerned, nothing indicates that having a non-Muslim husband is problematic, although she admits it would be ideal if her husband also converted to Islam. Her husband did not oppose to her converting to Islam but did ask her not to 'drag him in' (interview, October 2018). As no ethnographic information is available on other Japanese converts in the same situation as Kawada's, it is impossible to tell if they are marginalized in Japanese society or within the Muslim community. However, not having a Muslim spouse makes Kawada's experiences markedly differ from those of other Japanese Muslims, especially Japanese women who are married to foreign-born Muslims. It is particularly significant that Kawada does not face the difficulty these women may experience in making their understanding of Islam respected by their spouses (see Section 3 for more). Finally, the fact that Kawada does not have children also makes her experiences different from those of other married Japanese women, many of whom have children. ${ }^{14}$ Parenthood is a role which causes Muslims residing in Japan to experience difficulty, for example in negotiating with schools regarding the practical needs of Muslim children, such as securing prayer spaces and following Islamic rules concerning diet and clothing (Sato 2015, pp. 99-123). Understandably, this perspective is largely absent in Kawada's narrative, though she is aware of those issues through interacting with other Japanese Muslim women. ${ }^{15}$

\section{Marginality Derived from Being a Muslim}

In contemporary Japan, Muslims are generally regarded as religious and cultural Others. While Japanese views of Islam before 1945 display some significant variations according to socio-political context (see for example, Obuse 2011; Sugita 1995), those currently found are often overtly negative, due to the post-9/11 discourse on Islam that associates Muslims closely with violence and terrorism. ${ }^{16}$ Islam is commonly viewed as a radical/extremist religion, associated with such things as intolerance, terrorism, strict regulation, the subjugation of women (J: danson johi) and blind commitment to faith (Tanada 2015, pp. 84-85). Some favorable views-albeit in small numbers-are also present, such as

13 The common values she points out include the sense of 'heaven' watching one's actions, filial piety (J: oyakōkō), cleanliness and patience (Kawada 2004, pp. 209-17). Similarities between Japanese and Islamic values have been pointed out by other Muslims (e.g., Higuchi 2007, p. 238).

14 In the survey conducted by Terada (2003, p. 138), approximately 80 percent of the informants had one or more children.

15 For more on ethnic Japanese Muslim women's experiences with these issues, see, for example, (Kanayama 2011; Kudo 2008, pp. 176-84; 2009, pp. 124-26). It should be pointed out that ethnic Japanese Muslim men, as fathers, do also get involved in these processes of negotiation (e.g., Sato 2015, pp. 103-6). As negotiation with a local school requires detailed discussions in Japanese, it can be surmised that it is not a gender specific task but is taken up by the parent who is more fluent in Japanese and more familiar with the Japanese school system.

16 A clear shift in Japanese students' perceptions of Islam is noted, for example, in (Kawada 2004, pp. 9-12). Higuchi, who was president of Japan Muslim Association at the time of 9/11, received a large number of queries to the effect that Islam is a religion that condones violence (Higuchi 2007, p. 169). 
Muslims being pious, sincere (J: majime) and family-oriented (ibid.), yet the concept of piety may have a negative connotation, pointing to the unfavorable impressions mentioned above. ${ }^{17}$ The negative perceptions of Islam have been reinforced whenever activities of extremist groups, such as ISIS, are reported. This is particularly true of cases in which Japanese citizens were kidnapped and/or killed, allowing these views to consolidate as widely cited stereotypes.

One salient example of such stereotyping has grown in popularity since the beginning of the twenty-first century. This is the discourse of a monotheism/polytheism divide that has a chauvinistic implication. Here, the ideas that Islam is prone to violence and that Islamic teachings are incommensurate with Japanese values are emphasized through distinguishing Islam and Japanese religions as monotheism and polytheism(s). While the distinction between Islam and Japanese religions (i.e., Shinto and Buddhism) itself has been a common one, invoked by both Muslims and non-Muslims, ${ }^{18}$ the current discourse of a monotheism/polytheism divide is notable in that the distinction is employed to highlight the notion that the Japanese, being polytheists, are more tolerant than monotheists. Although the term monotheists also refers to Jews and Christians, its particular interpretation as polarizing when applied to Muslims clearly emerged in reaction to the 9/11 incident as well as to the Taliban's destruction of the Buddha statues in Bamiyan. Indeed, most such discussions by Japanese intellectuals were published after 2001 (e.g., Kaji 2018, p. 248f; Yasuda 2006; Sadakata 2005; Yoro 2003, pp. 192-204; Umehara 2002, pp. 252-54; Kishida and Kotaki 2002, pp. 179, 236-237).

While the blanket criticism of the three Abrahamic religions has increased especially since 9/11, negative stereotypes about Christians and Jews have long existed in some segments of Japanese society. What is remarkable is that such views often do not primarily concern actual Jews or Christians. According to Goodman and Miyazawa (1999), anti-Jewish views such as that Jews are plotting to overtake the world, have tended to be expressed at times of social or economic instability, for example, to advance an exclusionist view (e.g., Goodman and Miyazawa 1999, pp. 398-403). Similarly, Paramore (2009) demonstrates that anti-Christian discourses have often been employed to advance political agendas which do not directly concern Christians. For example, the anti-Christian discourse in the late 1670s, when virtually no Christians existed in Japan, as 'brand' or 'tool for delineating intellectual political authority and heterodoxy and for attacking political enemies and ideas' (Paramore 2009, p. 7). In other words, Jews and Christians have been an imagined political enemy (or threat) and a symbol of cultural Otherness. ${ }^{19}$

It is not unclear, however, to what extent these anti-Jewish and anti-Christian discourses constitute the basis of the current discourse of the monotheism/polytheism divide centered on Islam. The antiJewish and anti-Christian perceptions that are discussed in Goodman and Miyazawa (1999) and Paramore (2009), respectively, do not problematize in particular the monotheistic nature of Judaism or Christianity in othering them, which is the central concept in othering Muslims. It is probably not so surprising that the categories of monotheism and polytheism were not mentioned specifically in pre-modern sources as they were not known then. Yet, the lack of reference to a similar distinction of one versus many objects of worship suggests a more recent origin of this particular discourse. While whether the negative stereotypes of Islam and Muslims currently held will develop into another symbol of cultural otherness and tool of social and political stigmatization remains to be seen, the ways in which they are expressed do show a similar tendency towards essentialization of culture and othering.

17 For more discussions of surveys of Japanese perceptions of Islam, see (Miura 2006; Matsumoto 2006; Komura 2015, pp. 208-12).

18 Japanese Muslims who mention this distinction do so either to problematize Japanese spirituality (e.g., Suzuki 2004, p. 78) or to highlight the difference between Islam and Buddhism/Shinto without criticizing the latter (e.g., Higuchi 2007, p. 119; 2011, p. 4).

19 Although it is beyond the scope of the present article, the question of why Christian mission has not been very successful in Japan, as in South Korea for example requires a careful consideration of Japanese religiosity. Of particular importance is will be its 'polytheistic' tendency and the strong focus placed on the family, which, taken together, can be incompatible with the idea of exclusive personal faith in one particular deity (e.g., Mullins 2005, pp. 221-26). The perception of Christianity as a 'foreign,' 'Western' religion (ibid., pp. 12, 241, 244) has also been a factor in its failure to be accepted in Japanese society, which is not unrelated to the above-mentioned characterization of Christians as the cultural others. 
The impact that these developments have had on everyday experiences of Muslims residing in Japan is not small. They are marginalized, if not 'criminalized,' not only in the popular discourse but also by the state. Some Islamic organizations have been placed under police surveillance, ${ }^{20}$ and have received messages of censure and threat. For example, Nagoya Mosque received phone calls of a threatening and censuring nature in the wake of the murder of two Japanese hostages by ISIS in Syria in February 2015 (Mainichi Shimbun 2015). Individual Muslims are also avoided or taunted in public (Kawada 2004, p. 166). ${ }^{21}$ Even Muslim schoolchildren have been taunted by their classmates, for example, for being possible terrorists (Sato 2015, pp. 28, 116; NHK Educational TV 2016). Thus, the worry of receiving negative comments or being treated with suspicion has become a common part of everyday life for Muslims in Japan. This has been highlighted by one ethnic Muslim man, who says that he always harbors fear of reprisals for being Muslim when speaking to a non-Muslim Japanese he is not yet acquainted with (Sato 2015, p. 168).22

Ethnic Japanese Muslims' awareness of their own marginality further influences the ways in which they deal with and present themselves to, Japanese society as a whole. For example, ethnic Japanese Muslims can be rather suspicious of individuals who approach them for information on their activities and views for the purposes of publication, whether they are the media people or researchers. As mentioned already, Kawada's initial reluctance to be interviewed for the present study was partly due to the disappointing experiences she had had with the media. A sense of weariness and refusal was also evident in one ethnic Japanese Muslim male leader in the Kanto area when the present author requested information on Japan Islamic Congress (J: Nihon Isuramu Kyōdan), a controversial Islamic organization active in the 1970s and 1980s (interview, July 2014). ${ }^{23}$ While part of his reaction was certainly due to the negative view he personally had about this group, it was equally clear that his reluctance to discuss the matter also came from a serious concern that coverage of the topic he viewed as a stigma in the history of Islam in Japan would further taint an already negative view of Islam. The effort made by Japanese Muslims to prevent negative impressions about Islam and Muslims from being generated is also seen in their decisions regarding authorship of publications on Islam intended for general Japanese readership. For example, Kawada was commissioned by Mimasaka Higuchi (1936-2019), former president of the Japan Muslim Association, to edit the volume Islam and Women mainly because she was not 'too strict' in her interpretations of Islam nor likely to make remarks likely to be unpalatable for non-Muslim Japanese readers (interview, October 2018) ${ }^{24}$ For Japanese Muslims who are spokespersons for their communities, it is of much importance to present themselves as taking a 'moderate' and culturally sensitive stance tolerable for wider Japanese society. ${ }^{25}$

Like many other Muslims residing in Japan, Kawada experiences marginalization resulting from following a religion held in common perception as violent and intolerant. For example, a senior Japanese man once said to her face-to-face, 'Islam is just like Aum Shinrikyo' (Kawada 2004, p. 13), a new religious organization responsible for the sarin gas attack on the Tokyo subway in March 1995.

20 This was noted in my interviews with a number of Muslims, both foreign-born and ethnic Japanese. For more on the police surveillance of Muslims in Japan, see (Takahashi 2018).

21 On the other hand, the number of visitors to major mosques in Japan has increased drastically after the hostage incident, due to people seeking to know more about Islam, a fact that has been viewed positively by some Muslims (Asahi Shimbun 2015).

22 The negative attitudes that the Japanese tend to have towards Muslims may partly be attributed to a general sense of suspicion and wariness towards religion and those who practice it (Sato 2015, pp. 68-69; Kawada 2004, p. 13). Indeed, Kawada observes that 'it is hardest to be understood by people who do not have religion.' The same point is made by another ethnic Japanese Muslim woman, who had more difficulty in getting the needs of her children understood by a public (i.e., non-religious) school than by a school affiliated with Buddhism (interview, October 2018).

23 For more on the Japan Islamic Congress, see (Obuse 2017).

24 Higuchi (2007, p. 226) argues that 'the raison d'être of Japanese Muslims lies in living in harmony with Japanese society without losing the spiritual and cultural qualities as a Japanese person.' For more on his experiences, see ibid., chapter 6.

25 Given their familiarity with Japanese culture, ethnic Japanese Muslims are in a better position than foreign-born Muslims to bridge to the Muslim community in Japan as a whole and to wider Japanese society (Obuse forthcoming; Matsuyama and Matsuyama 2011, pp. 83-86). Converts tend to actively play a role in bridging the Muslim community and the wider non-Muslim society, a tendency also noted in European contexts (e.g., van Es 2019a; Roald 2004, pp. 347-48; Zebiri 2008, pp. 82-87; Özyürek 2015, pp. 16-18). 
On a different occasion, another senior Japanese man told her that the Japanese do not engage in terrorist activities. Kawada responded to this strongly by reminding the man of the activities of the Japanese Red Army, a communism-inspired militant organization, in the 1970s and the 1980s. Upon hearing this, the man 'lost words' and had 'a very strange look on his face. ${ }^{26}$

Her criticism of non-Japanese people who are oblivious to historic acts of aggression perpetuated by the Japanese, including their military operations during the WWII, comes to the fore most strongly in her discussion of the above-mentioned monotheism-polytheism discourse. She regards it the 'most exasperating' of all the common Japanese perceptions of Islam today, calling the intellectuals who are involved in the production of the discourse in apparent ignorance of how intolerant the Japanese have been, 'self-righteous (J: dokuzenteki)' (interview, October 2018).

Kawada's doubt about the notion that the Japanese are 'tolerant' is also behind a more fundamental concern, namely, that a radical change in the social system might lead to a persecution of Muslims. ${ }^{27}$ Her fear about a possible loss of the freedom to practice Islam in Japan is not simply a hypothetical one, as 'there are people who argue that monotheistic religions should disappear because they are exclusive' (Kawada 2004, pp. 225-26).

\section{Marginality Deriving from Being Japanese}

Ethnic Japanese Muslims are further marginalized in Japanese society because they are Japanese. What underlies this is the prevalent notion that Islam is a religion for foreigners, as mentioned above. The attitudes of non-Muslim towards ethnic Japanese Muslims are heavily informed by the distinction between Japanese-ness and Muslim-ness, constituting category confusion (Komura 2015, p. 153). That being Japanese and being Muslim are considered as exclusive categories is clear from the questions that ethnic Japanese Muslims tend to receive from non-Muslim Japanese. They are often asked why they became Muslim or why they wear a headscarf or do not eat pork 'despite being Japanese (J. nihonjin nanoni)' (interview, January 2019; Komura 2015, p. 154; Kudo 2008, pp. 188-90; Kawada 2004, p. 166). This means that the Muslim-ness of ethnic Japanese Muslims is held more suspicious and more unacceptable than that of foreign-born Muslims. In other words, ethnic Japanese Muslims suffer 'inverted marginality', whereby the lack of foreignness, a factor that would generally lead to acceptance of the full membership of the person in the wider Japanese society, becomes basis for marginality. They are more marginalized because of belonging to the ethno-cultural majority of the country. Of course, the relative unacceptability of the religious background of ethnic Japanese Muslims does not simply mean that ethnic Japanese Muslims experience more difficulty living in Japan than foreign-born Muslims; the latter experience marginalization due to being foreigners, in terms not only of perceptions but in practical matters such as immigration, finding employment and renting accommodation (Kawada 2004, p. 179; Komura 2015, p. 132). ${ }^{28}$ However, foreign-born Muslims do not tend to be more discriminated against for being a Muslim than their ethnically Japanese counterparts (Obuse 2011, p. 196; Penn 2008, pp. 96, 99), since their Muslim-ness is regarded and accepted, as forming part of their foreign-ness.

That the extent of marginalization of Muslims within Japanese society depends on the extent of 'foreignness' they are seen to possess (Sato 2015, pp. 206-7) is noted by foreign-born Muslims and ethnic

26 Kawada notes that her relatively advanced age somewhat protects her from receiving discriminatory comments or treatments. This seems to be confirmed by the fact that the two examples cited here were both made by men who were older than her, although it is not clear if the factor of gender is also at play, that is, if Japanese women who are older than her would be as openly critical of Islam with her. She also observes that by being a woman, she is less likely to be called 'terrorist,' as more men than women are perceived as being actively involved in extremist activities (interview, January 2019).

27 In Kawada's view, the Japanese are 'indifferent' to people of different religious backgrounds rather than 'tolerant.' The frequent use of the word 'indifferent' that she makes, despite the joyful and relaxed manners in which she speaks, seems to reveal the general sense of disappointment she feels about not being accepted by her native society.

28 For more on migrant Muslims' experiences in Japan, see Higuchi et al. 2007. Disadvantage in employment, including inability to get permission to perform daily prayers or wear a headscarf at work, is also experienced by some ethnic Japanese Muslims (Sato 2015, pp. 64-67, 207-8). 
Japanese Muslims alike (ibid., pp. 62, 67; Komura 2015, pp. 153-54; Kawada 2004, p. 179). Foreign-born Muslims are less likely to face resistance from non-Muslim Japanese than ethnic Japanese Muslims on the basis of their religious background; being foreigners, they are not expected to conform perfectly to the social and cultural norms of Japanese society. It has also been observed that children born to mixed parents, that is, so-called 'hāfu' children and returnee children, that is, ethnic Japanese who grew up abroad, are also more likely to be tolerated for following customs that are based on Islam, because their foreignness derives from having a foreign parent and from exposure to a foreign culture respectively (Sato 2015, pp. 67, 206; Kudo 2009, p. 125).

Despite being Japanese, ethnic Japanese Muslims married to a foreign-born Muslim may also be partially exempt from the duty of conforming to mainstream social and cultural norms (Sato 2015, p. 67), because they are regarded as belonging less to the Japanese cultural sphere. ${ }^{29}$ However, this kind of tolerance has its downside. While they may be regarded as less suspicious or strange for practicing Islam than ethnic Japanese Muslims who are not married to a foreigner, having a foreign spouse can raise questions as to whether they are willingly practicing Islam, for example, wearing a headscarf. This is because they tend to be regarded as following the culture of their spouse simply out of necessity (Kudo 2008, p. 190). Although they may experience difficulty in the process of adapting to an Islamic way of life, such assumption disregards the agency of these women. Another problem is that tolerance that is granted on the basis of perceived foreignness does not necessarily lead to genuine understanding or acceptance; labeled as foreign, as Other, they are never accepted as bona fide members of society (Sato 2015, p. 207). Furthermore, the foreignness that the ethnic Japanese wives of foreign Muslims have acquired through marriage does not necessarily protect them from experiencing considerable difficulty in having their stances and needs understood by non-Muslim Japanese who expect them to conform to mainstream lifestyle. The problem comes to the fore when they have children, which makes it necessary for them to interact more with non-Muslims, notably in their local communities and at schools (Kudo 2008, p. 177f). To take an extreme example, a few ethnic Japanese Muslim women, each married to Pakistani Muslim men, were interrogated by the principal of their children's kindergarten for not letting their children eat pork. The principal called their capability as mothers into questions, saying: 'What nationality are you? If you insist on your child not eating pork in Japan, it will seriously hinder the healthy development of the child's personality' (Kudo 2014, p. 107). As the principal was aware that they were Japanese, the question was a rhetorical one, aiming to highlight the perceived unreasonable nature of their views and preventing them from violating the perceived 'cultural homogeneity' of the Japanese (ibid.). ${ }^{30}$

Ethnic Japanese Muslims, whether they are married to a foreign-born Muslim or not, also tend to face difficulty in dealing with their parents. In addition to initially expressing disagreement with their children's conversion to Islam, they may resist their adoption of a new lifestyle informed by Islamic teachings, in particular with regards to prohibitions on diet and proscriptions regarding clothing (Kawada 2004, pp. 201-2). Issues surrounding death and funerary rites can be very serious. For example, when an ethnic Japanese Muslim married to a foreign-born Muslim passes away, her family on the Japanese side may be opposed to burial (instead of cremation) and/or Islamic mortuary rites (Sakurai 2003, p. 189; Kawada 2004, p. 207). For ethnic Japanese Muslims, especially those who do not have family ties to other Muslims living in Japan, it is imperative that they make sure that, when they

29 Kudo (2008, p. 189) observes that for non-Muslim Japanese, ethnic Japanese Muslim women become 'an ambiguous presence, neither foreigner nor Japanese' when they wear a headscarf. Komura (2015, pp. 154-55), on the other hand, ethnic Japanese Muslims who are committed to practicing Islam are regarded as 'foreigners.' However, as shown through an example below, ethnic Japanese Muslims are expected to conform to Japanese social and cultural norms.

30 How much contact they have with wider Japanese society is also an important factor in the experience of ethnic Japanese Muslims. A Japanese Muslim woman who is married to a Sri Lankan Muslim man says (interview, October 2018) that she does not experience much difficulty dealing with Japanese society as she is married to a foreigner, adding that she does not have much contact with other ethnic Japanese anyway, since she works in her husband's business. 
pass away, their body will be treated in accordance with Islamic prescriptions. ${ }^{31}$ Moreover, in the cases like Kawada, where the spouse is not Muslim, there is an added issue concerning how to deal with their passing, potentially leading to a conflict with their family. Being aware of this potential difficulty, Kawada says she 'tells [my] husband not to die before me' (interview, October 2018).

Ethnic Japanese Muslims may further be marginalized within the Muslim community, by foreign-born Muslims, making them doubly outsiders (Komura 2015, p. 155). In other words, they suffer 'double marginality' (Zebiri 2008, pp. 52, 62), a phenomenon also observed in European contexts, where converts face prejudice and pressure to conform from non-Muslims and born Muslims alike. A salient example involves the issue of the headscarf (discussed in more detail in the following section); converts have to deal with the prejudice from the non-Muslims who regards the practice as the symbol of female oppression on the one hand, and experience a peer-pressure from born Muslims to wear the headscarf, to be regarded as a proper Muslim, on the other (Allievi 2006, pp. 126, 129, 131, 140). The pressure to practice Islam properly from born Muslims is part of the broader experiences that converts have in encountering born Muslims. This often involves a sense of disappointment and even conflict (e.g., Roald 2004, p. 253; 2006, p. 50), which is also true of the experiences of some Japanese converts (Obuse forthcoming), including Kawada (see below).

While the marginalization of ethnic Japanese Muslims by the wider Japanese society is based on the above-mentioned ethno-cultural distinction, that by foreign-born Muslims may derive from the fact that the vast majority of them are converts, rather than it having to do with their ethnicity (i.e., Japanese-ness) per se. Ethnic Japanese Muslims are often criticized by foreign-born Muslims for their ways of practicing or interpreting Islam, as a result of the sense of superiority that 'born Muslims,' that is, those who are more thoroughly rooted in the tradition, have towards religious 'newcomers.' Two patterns can be highlighted for the marginalization of ethnic Japanese Muslims by foreign-born Muslims. In the first pattern, the stances of ethnic Japanese spouses of foreign-born Muslims are sometimes disrespected. This tends to be found in couples where the woman is an ethnic Japanese convert and the man a foreign-born Muslim; difficulty results from disagreement with their spouses over correct interpretations of Islam (Komura 2015, pp. 136-37; Sato 2015, pp. 94-96, 143-54; Kawada 2004, pp. 188-89; 2011, p. 28). It takes place as the wife learns more about Islam, for example, through study groups with other ethnic Japanese Muslim women (Kudo 2008, chapter 5; Kawada 2011, pp. 35-44). One significant factor in such disagreement is the tendency among some foreign-born Muslims to mistake the customs of their native country or region for representing correct Islamic practice, which can cause confusion for ethnic Japanese Muslims (Kawada 2011, pp. 25-26; 2004, pp. 187-88). ${ }^{32}$ The other pattern is when foreign-born Muslims challenge the views of ethnic Japanese Muslims who are familiar with traditional Islamic teachings. For example, an ethnic Japanese Muslim who received training in Islamic jurisprudence often has his interpretation of what is permissible of Japanese social and cultural practices, such as bowing, in terms of Islam criticized by foreign-born Muslims. Noting that his interpretations are informed by the need that ethnic Japanese Muslims have to maintain a good relationship with their non-Muslim families and the wider Japanese society, he argues that the goal of ethnic Japanese Muslims is different for that of foreign Muslims (Obuse forthcoming). The difficulty experienced by ethnic Japanese Muslims vis-à-vis foreign-born Muslims may further by attributed to the fact that they do not have their own ethnic community that is self-sufficient, an issue highlighted by Kawada in the discussion below. ${ }^{33}$ Despite such limitation, some ethnic Japanese

31 To be prepared for the death of fellow Muslims, seminars on mortuary rites are organized and mutual-help networks established (Kawada 2004, pp. 204-5; Kawada 2011, pp. 41-42).

32 It has to be emphasized that not all Japanese women married to foreign-born Muslim men report experiencing difficulty in adopting Islamic practice, as the attitudes of foreign-born Muslim men are not monolithic. Kudo notes that some Pakistani men married to Japanese women develop their identity from being 'born Muslims' to being 'true Muslims'. This is achieved through having more opportunities to study Islam in Japan (Kudo 2008, pp. 102-3, 170).

33 The importance of the help and advice that ethnic Japanese converts get from foreign-born Muslims is noted by Kawada (2004, p. 189). 
Muslims are responding actively to the challenge posed by foreign-born Muslims by outgrowing 'Pakistani customs' to acquire a perspective on 'real Islam' (Kudo 2007, pp. 17-18; 2008, pp. 158-63) or attempting to 'indigenize' Islam in Japanese contexts (Obuse forthcoming).

As with other ethnic Japanese Muslims, Kawada emphasizes the feeling of marginality she experienced through becoming a Muslim 'despite being Japanese.' She described the sense of alienation she felt, saying, '[Y]ou suddenly become a [member of a] "minority" [group], an "alien (J: ijin)" in an environment you had been so familiar with. It may be hard to understand for those who have never had such experience. It is fairly tough to go through if it really happens to you. Those [Muslims] who come from abroad, although they are Muslims too, can never understand what it is like' (Kawada 2004, p. 179). As discussed in more detail in the next section, her experience of marginality is exacerbated by the fact that she often wears a headscarf, a custom that is heavily resisted by non-Muslim Japanese, who tend to ask her, 'Why do you do such a thing despite being Japanese?' (Kawada 2004, p. 179). Kawada likens her experience of being treated like an alien in her homeland to 'falling outside of the "harmony (J: wa),"' a reference to the saying attributed to Prince Shōtoku (574-622): 'Harmony is to be valued (J: wa o motte tōtoshi to nasu), ${ }^{\prime 34}$ the spirit of which she regards as '...still very much alive in Japanese society today' (Kawada 2004, p. 180).

In response to the marginalization she has experienced as a Muslim, Kawada challenges the assumption held among the Japanese that Islam is a foreign religion or a religion for foreigners (Kawada 2011, pp. 3-4). Her critique is developed against the backdrop of what she regards as the Japanese tendency to be partial towards things Western. 'I am often asked why I became Muslim despite being Japanese. I would like to ask them, conversely, if it is wrong for a Japanese person to be Muslim.... On the other hand, the Japanese people take to American and European things quickly' (interview, January 2019). The same critical perspective is also applied to the issue of clothing, allowing her to further re-evaluate the attitudes of mainstream society. 'Some [ethnic Japanese Muslim women] are asked why they are dressed like that despite being Japanese but is it wrong for a Japanese person to be dressed like that? What is the style becoming of a Japanese person (j: nihonjin rashii kakkō)? Nowadays very few people wear traditional Japanese dress. Everyone walks around in Western clothes, whether they suit them or not. I wonder if [a foreign dress] is accepted if it is Western' (Kawada 2004, pp. 166-67).

Kawada's criticism of the uncritical acceptance of Western culture among the Japanese goes in hand in hand with a critical examination of the concept of 'individuality' and what it means in Japanese society. She says: 'In Japan we often say, "we should respect individuality [of each person] (J: kosei o taisetsu ni)." Despite [the presence of such a slogan], you get stared at if really dressed differently. The term "individualistic (J: koseiteki)" in the Japanese view seems to mean that you show some [difference] while conforming to the mainstream [culture]' (Kawada 2004, p. 167). ${ }^{35}$ She further points out that, due to the social pressure to conform, it is difficult if not impossible for people who do things differently to associate closely: 'Japanese people seem to think that they should do the same as others in order to be regarded as accepting them. But isn't it okay for you to be you and for me to be me?' (interview, January 2019).

That Kawada has acquired a new perspective on Japanese society and its values through becoming a Muslim is particularly clear in her attitude to the idea of social harmony mentioned above. She challenges what she regards as an over-emphasis present in Japanese society on conformity to the majority culture and critiques the lack of clarity of what is expected of individuals. She says, 'they often say that Islam has strict rules (J: kairitsu ga kibishii) but the unwritten laws of Japanese society are so much more cumbersome.' She admits that she is not good at 'reading the atmosphere,' that

34 This is the beginning of the Seventeen-Article Constitution. The translation is taken from (George 1896, p. 128-33). The Japanese provided shows how it is commonly read.

35 A similar point is made by an ethnic Japanese Muslim woman married to a Pakistani man, who has lived in an English speaking country, when she says, 'it is not allowed for each individual to be different in Japan' (Kudo 2009, pp. 126-27). 
is, figuring out how she is expected to behave in different social settings, giving an example of an occasion in which she was admonished by her Japanese colleagues for behaving in a way that she should not have done (interview, October 2018). Her familiarity with Islamic teachings has given her a comparative perspective, which has enabled her to understand what aspect of Japanese society made it hard for her to conform to the rules about social manners.

For Kawada, who has been practicing Islam for over twenty years, however, the biggest challenge in living as a Muslim in Japan is her relationship with other Muslims. She even said on one occasion that internal issues, especially relationships with foreign-born Muslims, are harder to handle than dealing with the wider Japanese society (interview, October 2018). She observes that new ethnic Japanese converts can be overwhelmed by the amount of information as to Islamic practice given them by foreign-born Muslims or discouraged by harsh words of admonition for their perceived mistakes (Kawada 2004, pp. 189-91). At various points in the interviews, Kawada also indicates that she too finds scrutinizing comments made by other Muslims about her approach to Islamic practice unpleasant and cumbersome. The tendency to scrutinize other Muslims' behaviors, sometimes on the basis of over-interpretation of the rules, is found among foreign-born Muslims and ethnic Japanese Muslims alike (Kawada 2011, pp. 26-27). ${ }^{36}$ This is partly why Kawada is against the spread of the recourse to halal certifications. She would not like to be criticized more often for eating non-halal food simply because the food does not have a halal certification logo, although her concern is not only about receiving criticisms. As indicated by her question 'So, who decides what is halal?' (interview, January 2019), her reservation about halal certifications stems also from the possibility that some Muslims will regard certifications, which are devised by human beings rather than Allah, as having the authority to decide what is permissible. ${ }^{37}$

To respond more efficiently to the criticisms posed by foreign-born Muslims, Kawada regards it an extremely important task for ethnic Japanese Muslims to produce a Japanese authority on Islamic jurisprudence. She says rather bluntly: 'In order not to let foreign Muslims impose their views [on us], we need properly qualified Japanese leaders' (Kawada 2011, p. 25f), ideally, those trained in Islamic jurisprudence at Al-Azhar University (interview, October 2018); graduates of a prestigious institution for Islamic learning would command much respect. Yet, what is really at the stake is the need for informed advice by those who are versed with Japanese culture and Islamic jurisprudence alike. Kawada notes that very few mosques have leaders 'who can teach Japanese people'; they need 'leaders who have the knowledge and the flexibility to answer the questions [of ethnic Japanese Muslims] concerning how to uphold Islamic teachings in life in a society that is not particularly compatible with them (Kawada 2011, pp. 25-26). ${ }^{\prime 38}$ The experience of double marginality felt by ethnic Japanese Muslims is clearly reflected in this expression of an urgent need to develop their own pool of qualified leaders, that is, to make their own ethnic community more self-sufficient.

\section{Marginality Derived from Being a Woman}

The marginality that ethnic Japanese Muslim women experience is further exacerbated by their gender. The major factor in the gender-based marginalization of ethnic Japanese Muslim women is gender orientalism (e.g., Minesaki 2015, 2f), a trend also widely observed in European contexts. It manifests itself most typically in the view that women are oppressed in Islam, thus a pitiable existence needing emancipation. The idea that Islam is backward and incommensurable with contemporary European values, as mentioned above, is often based on the female practice of wearing headscarves.

36 Conflict among ethnic Japanese Muslim women is also noted in (Komura 2015, pp. 142-47).

37 Concerns about halal certifications have also been voiced by other ethnic Japanese Muslims.

38 This may contradict the above-mentioned view that there are many commonalities between Islamic and Japanese values. However, she seems to be concerned here about the need to explore ways to practice Islam that are suitable for Japanese contexts. That she values such attempts of indigenization is indicated, for example, by her reference to how Buddhism, which was initially a foreign religion, like Islam is, has managed to spread widely in Japan (interview, January 2018; Kawada 2004, pp. 20-21). 
Indeed, 'Western society has made the hijab and the subordinated position of women into symbols of the "Otherness" of Islam' (Jansen 2006, p. 7). This has led to great suspicion, even hostility towards women who voluntarily convert to Islam; they are 'traitor[s] to the race' (van Nieuwkerk 2006, p. 1). Some Muslim women and even men, have responded to this stereotype by arguing the opposite, that it is the non-Muslim women that are unfree in that they are expected to look beautiful and sexy (e.g., Allievi 2006, p. 120; Bourque 2006, p. 246), thereby critiquing the values and social practice of the non-Muslim mainstream society. Some Muslim women, especially converts, actively attempt to challenge and correct the negative stereotypes concerning the position of women in Islam, not only by writing or speaking about the topic publicly but also through their own behaviors in everyday interactions with non-Muslims (van Es 2019a, pp. 379-83).

To make the situation more complicated, however, the attitudes to the practice of wearing a headscarf are also diverse within the Muslim community, partly because no clear injunction is provided on the practice in the Qur'an. This at times leads to a conflict. For example, those who do not wear one or who are perceived as not wearing it properly can be regarded as not fully Muslim by their fellow Muslims who do (Allievi 2006, p. 140). The former, on their part, attempt to justify their choice vis-a-vis the latter and to establish their identity as a Muslim. It is also to be noted in this context that the process of converts adapting to Islamic practice and finding their own stance is often a long-winding one, where their understandings of Islam as well as self-perceptions are constantly revised (Allievi 2006, p. 144; Bourque 2006, p. 238). Thus, the headscarf, as the issue of gender (i.e., women) in general, is a significant space for social, cultural and political contestation, on which the identity of each society and each individual, rests.

The perception that women are discriminated against in Islam, as seen above, is widespread in Japan and constitutes, as in European contexts, a basis of viewing Islam as the culture Other, something opposed to Japanese values. One common way in which this manifests itself in Japanese contexts is ethnic Japanese Muslim women being asked to defend Islam against the commonly held perception that Islam subjugates women. For example, Kawada (2004, p. 147) reports the response of a long term friend of hers when she told her of her conversion: 'Islam is a religion of female discrimination (J: josei sabetsu). Why on earth did you join such a religion?' Like European converts, Kawada's response to such criticism involves a critique of the mainstream Japanese society. She is particularly critical of Japanese men who dare to say that Islam discriminates against women, while not hesitating to do or say things that clearly constitute sexual harassment (interview, October 2018). In challenging such perceptions, she reiterates her criticism of the Japanese for accepting Western things uncritically, saying that Japanese 'criticism of Islam is made through a Western perspective;' 'I do not want Japanese people to tell me that Islam discriminates against women. They like talking about a gender equal society but what is so equal about Japanese society?' (interview, October 2008).

Kawada's experience of becoming the target of such blunt criticism or cultural othering, ${ }^{39}$ has led to the acquisition of a new perspective on Japanese society and the treatment of Japanese women in it. She says she never experienced disadvantage for being a woman prior to her conversion, attributing this partly to her lack of career ambition; she never identified herself to be a 'minority' of any sort (interview, October 2018). While she detected some marginalization of women in her native society, she did not have a strong opinion about gender equality nor develop a particularly feminist attitude. Nothing in her narrative indicates that, prior to her conversion, she subscribed to the idea that Islam is a religion of female subjugation, either. However, her new religious identity, with its accompanying experience of marginality, has forced her to revise her perspective on the society she had comfortably lived in

39 As will be discussed below, the cultural othering of Japanese Muslim women takes the most direct form when they are wearing a headscarf. In responding to this, however, they also objectify non-Muslim people as 'normal Japanese people'; the process of othering operates both ways around (Kudo 2008, p. 134). This means that converts, like their non-Muslim fellow citizens, are guilty of cultural essentialization. This can, as observed in European contexts, lead to self-essentialization, where their identity is reduced to a single element (van Es 2019a, p. 388). 
previously. The phenomena that she had been aware of, that is, how Japanese men behave towards women and how Japanese women behave in Japanese society, has undergone critical examination, both in response to the criticism she has received about Islam and in light of the new experiences she has had as a Muslim.

That Kawada draws on her experiences with fellow Muslim women in developing a new stance is clear in her view of Japanese women. She observes that, contrary to the claim that Japanese women are freer than Muslim women, Japanese women are 'unfree' in that female professionals face constant pressure to perform as well as men and that, more broadly, Japanese women are forced to accept rude comments about their appearances, explicit remarks made by men and the sight of men reading adult material in public. While noting the persistent problem of the commodification of female sexuality in Japanese society, Kawada's criticism is also directed towards Japanese women, who, according to her, lack 'dignity,' pursuing amicability over the development of a dignified comportment (Kawada 2004, pp. 161-63; interview, January 2019).

The tendency to direct criticism concerning the treatment of women in Islam at ethnic Japanese Muslim women can take a more subtle form in media coverage of Islam. As mentioned above and confirmed through Kawada's experiences detailed below, media coverage tends to reproduce the perception of Islam as discriminatory against women on the one hand and present Japanese Muslim women challenging this view on the other. ${ }^{40}$ The excessive media focus on the position of women in Islam that Kawada perceived in her experiences with two mainstream newspapers eventually led to her decision never to accept interviews by the media.

The first instance was her interview with Asahi Shimbun in 2011, where she was requested to speak about 'what the Qur'an is for ordinary Muslims, rather than for scholars.' At the very end of the long interview, the interviewer asked, 'so what do you think about women?' She replied, saying '[W]ell, I do not think they are discriminated against in Islam,' only to find to her astonishment that 'only that one line was published [in the article]' (interview, October 2018). In reality, however, the article mentions her conversion experience, which was triggered by hearing a Qur'anic verse recited, as well as her response to the question of the position of women in Islam, including her explanation of why polygamy was allowed at the time of Prophet Muhammad and how hard it is to practice it without violating the conditions set out in the Qur'an (Asahi Shimbun 2011). The fact that Kawada remembered the content of the article in the way she did indicates how disappointing the whole experience was for her. Her selective memory about what actually went into the article may have been her reaction to what she felt was its excessive focus on the issue of the position of women in Islam, coupled with the many comments of a judgmental nature she had personally received. It is also possible that the impression that only one line of what she said was published resulted from her disappointment in seeing so little of the personal stories she had shared with her interviewer reflected in the published article.

Kawada's experience with Mainichi Shimbun also resulted in similar disappointment. Prior to the interview, she indicated to the interviewer her hesitation to cooperate, citing her experience with Asahi Shimbun. She agreed to cooperate after hearing the interviewer's intention was completely different and talked at length on two occasions about her 'conversion and everything [about her faith]' (interview, October 2018). When she saw the published article, which mentioned only the topics of 'halal food and women' (meeting, August 2018), she decided that she 'had enough' (interview, October 2018). The article discusses the subject of halal food, alongside a picture of her in a nearby halal grocery shop and briefly mentions her view of the treatment of women in Islam: 'While there is a view that

40 See, for example, (Kunifuda 2017). Further research on Japanese Muslims' experiences with the media should be conducted to examine how persistent this pattern is. One straightforward reason Muslim women are more likely to be asked about the treatment of women in Islam would be that they can speak from their own experiences, thereby providing a reliable source of judgment. However, the tendency for the female comments published to be limited to those on the topic of the treatment of women and not others may point to a genderized concept of authority; men are granted the authority to speak about Islam as a whole, while women are limited to commenting on culturally female experiences of being Muslim. 
the position of women is low in Islam in that it allows men to have up to four wives, Kawada says there are many women who are living with dignity' (Mainichi Shimbun 2016). However, the article also includes a description of her study group, where three Japanese Muslim women, presumably including her, discuss what it is like to have an Islamic faith. Therefore, although reference to the issue of faith was not completely absent, Kawada's description of the article as solely focused on the issue of halal food and women can be considered to reflect the above-mentioned sense of disappointment that the article focused on such stereotypical topics, ${ }^{41}$ disregarding matters that were of more importance to her. The conclusion she reached after her experience with the two newspapers, that her effort was wasted (interview, October 2018), is thus a reflection of the idea that media coverage would not lead to genuine understanding of Islam or Muslims. She concluded that in general non-Muslim Japanese are not really interested in knowing about Islam, let alone understanding her experiences, a feeling which is reflected in her description of the Japanese mentioned above (in note 27) as 'indifferent.'

The marginalization of Japanese Muslim women on the basis of a negative view of how women are treated in Islam also reflected in the ways in which the practice of wearing a headscarf is perceived. Unlike in some European countries (e.g., France), the issue of headscarf has not been a subject of public debate nor target of official ban in Japan. This can partly be attributed to the small number of Muslims residing in Japan. However, the marginality of Japanese Muslim women is clearly reinforced when they wear a headscarf. It renders their Muslim-ness visible, making them more subject to comments or reactions of a denigrating nature. Some are disallowed or are pressurized not to wear a headscarf by those around them, for example, family members and superiors at their workplaces (Sato 2015, pp. 62-68; Komura 2015, pp. 127-28; Kudo 2008, pp. 184-89). Generally speaking, such responses are the results of resistance, disdain or a sense of discomfort on the part of non-Muslims. In these cases, Japanese Muslim women wearing a headscarf become the visible targets for critiques of Islam regarding its supposedly discriminatory treatment of women, as well as personal criticism for following what is regarded as an unacceptable practice. ${ }^{42}$ For those who are unwillingly wearing a headscarf, for example because they are asked to do so by their Muslim husband, this creates an experience of double marginality, potentially thrusting them into a serious dilemma. The discussion of Kawada's experience below also suggests she has suffered double marginality; she was looked on suspiciously by non-Muslim Japanese because of her headscarf and has also been criticized by her fellow Muslims for her way of wearing a headscarf.

In addition to becoming the direct target of criticism concerning the treatment of women in Islam, ethnic Japanese Muslim women wearing a headscarf are also objects of pity resultant from an assumption that they are forced to wear one by Muslim spouses. Here, the discourse of gender orientalism which projects Islam as a religion of female subjugation takes the most profound shape; viewed as an oppressed existence, ethnic Japanese Muslim women wearing a headscarf are deprived of agency. An ethnic Japanese couple (Matsuyama and Matsuyama 2011, pp. 95-96) provides two episodes to confirm this, observing that wives of Japanese Muslims are more likely to be misunderstood than their husbands (ibid., p. 96). ${ }^{43}$ In the first, a Japanese person from their locality, upon learning that the wife was Japanese, said to her, 'Islam is a religion of female subjugation. I feel for you [J: taihen nē].' In the other, a friend of theirs assumed that the wife, who was already a practicing Muslim before getting married, was made to convert to Islam in order to marry him. Upon learning that it was her

41 In the Asahi article, the topic of women is introduced as follows: 'Not a few Japanese people have a preconceived idea (J: sen-nyūkan) that Islam subjugates women (J: danson johi). Is it really the case? (Asahi Shimbun 2011).' While the use of the term 'preconceived idea' suggests the writer is aware of the possibility that it is an ungrounded, unfair judgment, 'danson johi,' which literally means 'respect men belittle women,' is a fairly strong expression, compared with 'josei sabetsu [discrimination against women]' or 'dansei chūshin shugi [androcentrism].'

42 The reactions they receive from the wider Japanese society when wearing a headscarf is also perceived positively, as, for example, they 'feel equal to men' (Kudo 2008, p. 191).

43 In the following examples, the first remark was very likely made by a woman given the way she talked, while the gender of the second speaker is unknown. More research is required to examine if the attitude of 'pity' is found more commonly among women. 
choice, this person confessed: 'I had always felt sorry [J: kawaisō] for her because I thought she was unwillingly covering her hair.' Although these remarks are both well-meant, they demonstrate the perception that Japanese women who are married to Muslim men are forced to follow a foreign custom (ibid., p. 96). The victimization of Japanese Muslim women as passive recipients of discriminatory treatment thus leads to the denial of active agency that they exercise in their lives as Muslim women.

Kawada has her share of bitter experiences resulting from wearing a headscarf, which has caused some transformation in her attitude. ${ }^{44}$ She says that the greatest discomfort she experienced was being stared at by strangers, who would 'stare all over you, up and down'. She describes the psychological damage she had from these gazes, comparing it to the effect of 'evil eye', which brings misfortune on the person that is looked upon (interview, January 2019; Kawada 2004, pp. 165-66). ${ }^{45}$ This made it hard for Kawada to wear a headscarf. In her 2004 book, she admits not wearing one when she is 'mentally tired', that is, when she feels she cannot cope with the impact of the critical gaze of strangers. Even when she does wear one, she sometimes wears it 'in the way that is not in accordance with the prescription of the Qur'an [24: 31] that [women's head-coverings] "should be worn over their bosoms."' This is immediately followed by an admission that her style is not acceptable to 'Muslim women who always wear their headscarves properly,' which suggests that Kawada had been criticized by other Muslims for her approach to headscarf-wearing. She even calls what she regards as the 'proper' way of wearing a headscarf the 'Islamic style,' by which she seems to mean a style that covers the hair completely and hides the neckline. As if attempting to justify herself against her fellow Muslims, she explains her turmoil thus: 'It is not that I don't think I should wear one. I think this (i.e., being unable to wear a headscarf or to wear it properly) reflects the weakness of my faith and I am ashamed of it. But at the moment, this is the only way for a weak-hearted person like me to uphold my faith in Islam in Japan. Of course, I am not thinking I can continue like this forever. I resent myself for worrying about the gaze of people around me more than about Allah and the situation also makes me question the way of Japanese society where one is criticized just for dressing differently. Why do I have to be troubled for just one piece of cloth?'46

Now, nearly fifteen years on from the publication of her book, Kawada wears a headscarf more regularly. She does not wear one when she is under time constraints but does not feel as uncomfortable as she used to when wearing one (meeting, March 2019). She wears her headscarf in a style where the scarf is tied at the nape of her neck, which is the style that she mentions in her book as not being in accordance with the teaching of the Qur'an. Wearing the headscarf in the way she does avoids being stared at but would still be considered 'strange' in the sense of being an unusual style; 'she must be thinking that is fashionable, poor her!' (interview, January 2019).

When I first asked her about her way of wearing a headscarf, she said that she wears it in the style she does because it does not make it easy for others to identify her as a Muslim (interview, October 2018) but quickly added, 'I know it's not good [but] ... (J: yokunain dakedo nē).' It was a casual exchange made when we were walking outside, so I did not pursue the subject further. When I asked her about the issue of headscarf at more length (interview, January 2019), she sounded more confident. She challenged the view that the headscarf is the symbol of Islam on two main grounds. The first was

44 Kawada does not report much difficulty with her family members and colleagues but she lost a long-term female friend, who remarked to Kawada face-to-face that her appearance with a headscarf on made her uncomfortable or 'made [her] feel oppressed (interview, January 2019).' This is an unusual reaction in that the negative comment on the headscarf did not involve criticism of the Islamic practice or from the feeling of pity, although it is possible that the person had a general feeling against Islam.

45 Kawada is much more comfortable with being spoken to by strangers about her headscarf. Even when their attitude is one of suspicion, she can accept it by concluding that 'perhaps they have never seen [a person in a headscarf] (interview, January 2019).' Japanese Muslim women who wear a headscarf can also be mistaken for a Malaysian or Indonesian (Kudo 2008, p. 189; interview, January 2019).

46 Awkward feelings towards those who wear a headscarf properly are also experienced by other female converts (e.g., Kudo 2008, p. 143). 
that there is no agreed [i.e., correct] way of wearing a headscarf. ${ }^{47}$ To this, she added that Muslims in Central Asia wear a headscarf in the same way as she does. She further supported her view that the headscarf should not be regarded as the symbol of Islam by saying that some Muslims do not or cannot, wear one due to various circumstances,' while refusing on the other hand 'to be told that Muslims should not wear a headscarf' (interview, January 2019). The remark that circumstances prevent some women from wearing a headscarf may partly reflect the struggle that Kawada has experienced with the practice of headscarf-wearing. Her view of there being no one agreed way of wearing a headscarf, on the other hand, contradicts what she said in her book: her style is not strictly in line with Islamic teachings. This suggests that through the course of her self-reflection as well as her communication with other Muslims, she has revised her interpretation. In particular, the fact that she justified her way of wearing a headscarf, which she has elsewhere admitted was not ideal, by citing the example of Central Asian Muslims points to the possibility that Kawada has explored ways to convince other Muslims and perhaps herself, of the validity of her choice. Given how emphatically she has insisted that one of the biggest challenges in her life as a Muslim living in Japan is the scrutinizing comments and criticisms made by fellow Muslims about her practice, it is not surprising that she has needed to develop counter-arguments to such criticisms.

The difference of perspectives found between what Kawada said in her 2004 book and during the two conversations I had with her on the topic of headscarves very much attests to the above-mentioned observation made in European contests on how multi-staged the post-conversion process of socialization can be. It also shows that as converts' understanding of Islamic teachings and more importantly, how differently they can be interpreted and practiced, assists their quest for a mode of practice most convincing and comfortable for themselves. Kawada's reference to Central Asian Muslims, who are traditionally Muslim but do not wear headscarves in the same way, for example, as Southeast Asian Muslims do, finds a significant parallel in an Italian convert who agrees more with Somali women, who do not wear a headscarf or wear it 'in their own way' than with 'Arab women and other converted Italian women' (Allievi 2006, p. 139).

Although she has devised various ways to account for her approach to Islamic practice over the years, the ways in which Kawada discusses the issue of the headscarf suggest that the difficulty arising from her double marginality is still significant. The small concession she made to me that her style was not 'good' in the sense of being properly Islamic may also be partially explained by a fear of peer pressure. She may have mentioned the undesirability of her style to pre-empt possible criticism, a strategy she may have developed through experiencing scrutinization from others. On that particular occasion, my question also indicated that I was aware that her style was unusual, which may have caused her to be defensive.

In the interview in which she justified her style, Kawada admitted that many Muslims are still critical of her way of wearing a headscarf. However, her reaction was markedly different from what she wrote back in 2004. Dismissing them, she continued joyfully, 'but they are not Allah. [Whatever others may say,] I am most comfortable with this style.' This suggests that she has acquired a new perspective to protect herself from the negative impact resulting from the criticism of her fellow practitioners. It is of course not completely impossible that she simply refrained from making a statement like this in her book for fear of offending her fellow Muslims. However, her recourse to the notion of Allah as the only and ultimate judge of her actions strongly indicates that she has established her own way of wearing a headscarf through internalizing the meaning of Islamic faith. Whatever the case may be, her struggle over the issue of the headscarf has not completely finished; she, after all, still worries about 'the eyes of

47 While she does not directly challenge the view that the headscarf reflects the subjugated status of women, it is clear that she is against such a view when she quotes an Egyptian woman living in Japan who says, 'they ask, why do you dress like a woman who is subjugated? I wear a headscarf because I want to. I just wish they let me be' (Kawada 2004, p. 164). 
other people' (interview, January 2019). ${ }^{48}$ Yet, Kawada's experience of marginalization has led her to develop a more confident position concerning the headscarf, a position more deeply rooted in her faith, thereby strengthening her identity as a Muslim.

\section{Conclusions}

The present article has examined the experiences of ethnic Japanese Muslim women in terms of three modes of marginality: marginality deriving from being a Muslim, from being Japanese and from being a woman. It has analyzed how the factors of ethnicity and gender add to the marginality of ethnic Japanese women as cultural and religious Others both in strength and complexity. The discussion has shown that the lack of foreign-ness subjects ethnic Japanese Muslims to more suspicion and intolerance from the wider Japanese society than their non-ethnic Japanese counterparts, constituting a case of 'inverted marginality', the marginalization due to belonging to the ethno-cultural majority. This is exemplified by one of the common questions directed against them: Why are you Muslim despite being Japanese? Ethnic Japanese Muslims have also been shown to suffer 'double marginality', which places them under scrutiny from the wider Japanese society and foreign-born Muslims alike. It has been argued that this experience partly has resulted from the absence of a self-sufficient ethnic community of Japanese Muslims and that this makes them strongly wish for such a community.

Ethnic Japanese Muslim women's experiences of marginality exhibit a further dimension when they become direct targets for criticism of Islam as being a religion of female subjugation. Whether expressed through direct, confrontational remarks or expressions of pity towards women wearing headscarves, such notion of gender orientalism deprives ethnic Japanese Muslim women of their agency. Kawada's experience with the media also suggests that the discourse of gender orientalism is so typical that it marginalizes ethnic Japanese women further even in forums wherein it could allow itself to be challenged by them.

While their experiences of marginality are diverse, the present discussion has also argued that ethnic Japanese Muslims, especially women, respond to these various forms of marginalization actively. Kawada's case amply suggests that, by becoming a 'foreigner' in their own county and being criticized for practicing what is regarded as a religion of violence and female subjugation, ethnic Japanese Muslim women develop a new, critical perspective on Japanese society and its commonly held values. Moreover, the analysis of how Kawada has sought to establish her own stance toward the practice of headscarf-wearing has shown that the process of trying to respond to the challenges of marginality, whether it is from within or without the Muslim community, has helped her consolidate her identity as a Muslim.

The present study has also revealed a number of parallels that are present between the experiences of ethnic Japanese Muslims and those of European converts. These include the inverted marginality, that converts are treated with more suspicion, even hostility, by non-Muslims, than born Muslims in that they have opted for a tradition that is perceived as diametrically opposed to the mainstream socio-cultural values; double marginality of converts, that converts are criticized by their fellow non-Muslim citizens and the born Muslims of an immigrant background alike; and the multiple marginality of female converts, where the idea that Islam is a backward religion who keep women oppressed and unfree, notably through the headscarf, makes female converts even more susceptible to the perception that they are social and cultural outsiders. One attempt to challenge the negative stereotypes and the accompanying marginalization, observed in Japan and Europe alike, has been to indigenize Islam, that is, to develop a more culturally nuanced understanding of Islam in light of the

48 Also, the many years of experience of living as a Muslim seem to have further led Kawada to realize the complexity of the issues involved, including that of headscarf. At the very end of my last major interview, she said self-reflectively, 'it is difficult, very difficult. The longer I live as a Muslim the more difficult I feel it is' (interview, January 2019). 
socio-cultural contexts of the given society, than the ways of Islamic practice informed by immigrants' cultural backgrounds (Obuse forthcoming).

The discourses concerning Islam and Muslims in Japan, on the other hand, differ from those in European contexts, partly in that they are not as politicized. Although Muslims residing in Japan, like their European counterparts, have been placed on police surveillance and been subject to suspicion in general, the lack of political debate on Islam, such as potentially banning the use of headscarf in public, has prevented collective alienation of Muslims from happening so far. This may be because the Muslim population in Japan is still small and their social and political presence is minimal. That no extremist attacks have taken place in Japan may also explain the relatively contained criticism of Islam and Muslims as violent on the popular level, although some Muslims have indeed been taunted or censured for following the tradition that is perceived to be the basis of the extremist activities perpetrated by ISIS, for example.

The most notable aspect of Japanese perceptions of Islam, which is not found in the European counterparts, on the other hand, is the discourse on the polytheism/monotheism divide which has shown a significant development since the $9 / 11$ incidents. Based as it is on Japanese religiosity and the traditional representation of it, this is certainly a development specific to Japan; it would not make as much sense in European societies, where the dominant religiosity has been formulated on the basis of Christianity. In serving the function to differentiate Islam and the mainstream non-Muslim culture and to emphasize the superiority of the former over the latter, however, this discourse is not as different from the European view of the headscarf as the symbol of the cultural otherness of Islam. Whatever the extent of actual discrimination against Muslims in Japan, the move towards collectively demonizing Muslims has already been made with this discourse. While more investigation is required of the origin and development of this discourse, it is possible to say that it fulfills the function that the debate on the headscarf plays in many European societies; that the cultural othering of Islam is being achieved through the recourse to the foreignness of Islam as an intolerant monotheism.

While the analytical framework for the compound marginality of ethnic Japanese Muslim women put forward in the present work is expected to have fairly general applicability, the diverse ways in which the three modes of marginality manifest themselves should be explored in more detail and examined alongside the situations surrounding converts in other non-Muslim majority societies further. This can be done through examination of ethnic Japanese Muslims' experiences with the media, the experiences of ethnic Japanese Muslim couples and of how the experiences of ethnic Japanese Muslims who are not married to Muslims differ from those of ethnic Japanese Muslims who have a foreign-born spouse. It will also be useful to further explore how the three modes of marginalization operate in relation to other factors such as social status and educational background, as well as the socio-political situations of the mainstream society as a whole.

Funding: This research received no external funding.

Conflicts of Interest: The author declares no conflict of interest.

\section{References}

Allievi, Stefano. 2006. The Shifting Significance of the Halal/Haram Frontier: Narratives of the Hijab and Other Issues. In Women Embracing Islam: Gender and Conversion in the West. Edited by Karin van Nieuwkerk. Austin: University of Texas Press, pp. 120-49.

Asahi Shimbun. 2011. Hajimete no Kōran [Reading the Qur'an for the First Time]. September 5.

Asahi Shimbun. 2015. Isuramukyō Shiritai: Shibuyano Mosuku, Kengakusha Nibaini [We Want to Know Islam: Visitors to a Mosque in Shibuya Doubled]. March 23. Available online: https://www.asahi.com/articles/ ASH3G62Z8H3GUTIL01B.html (accessed on 16 July 2019).

Aston William George, trans. 1896. Nihongi: Chronicles of Japan from the Earliest Times to A.D. 697. London: Keagan and Co., vol. 2. 
Bernt, Matthias, and Laura Colini. 2013. Exclusion, Marginalization and Peripheralization Conceptual Concerns in the Study of Urban Inequalities. In IRS Working Paper 49. Erkner: The Leibniz Institute for Regional Development and Structural Planning.

Bourque, Nicole. 2006. How Deborah Became Aisha: The Conversion Process and the Creation of Female Muslim Identity. In Women Embracing Islam: Gender and Conversion in the West. Edited by Karin van Nieuwkerk. Austin: University of Texas Press, pp. 233-49.

Fujita, Tomohiro. 2017. Isurāmuken kara no Kankō to Harāru. In Ikyō no Nyūkamātachi: Nihon ni okeru Imin to Shūkyō [Newcomers with Foreign Religions: Migration and Religion in Japan]. Edited by Hizuru Miki. Tokyo: Shinwasha, pp. 49-64.

Goldberg, Chad Alan. 2012. Robert Park's Marginal Man: The Career of a Concept in American Sociology. Laboratorium 4: 199-217.

Goodman, David, and Masanori Miyazawa. 1999. Yudayajin Inbōsetsu: Nihon no naka no Hanyudaya to Shinyudaya [Jews in the Japanese Mind: The History and Uses of a Cultural Stereotype]. Translated by Fujimoto Kazuko. Tokyo: Kōdansha.

Gooren, Henri. 2010. Religious Conversion and Disaffiliation: Tracing Patterns of Change in Faith Practices. New York: Palgrave Macmillan.

Higuchi, Mimasaka. 2007. Nihonjin Musurimu to shite Ikiru [Life as a Japanese Muslim]. Tokyo: Kōsei Shuppansha.

Higuchi, Mimasaka. 2011. "Hajimeni" [Introduction]. In Kasuke Iimori. Isurāmu to Nihonjin [Islam and the Japanese]. Tokyo: Kokusho Kankōkai, pp. 3-5.

Higuchi, Naoto, Nanako Inaba, Kiyoto Tanno, Tomoko Fukuda, and Hirofumi Okai. 2007. Kokkyō o Koeru: Tainichi Musurimu Imin no Shakaigaku [Crossing Borders: A Sociology of Muslim Migrants in Japan]. Tokyo: Seikyūsha.

Iimori, Kasuke. 2011. Isurāmu to Nihonjin [Islam and the Japanese]. Tokyo: Kokusho Kankōkai.

Jansen, Willy. 2006. Conversion and Gender, Two Contested Concepts. In Women Embracing Islam: Gender and Conversion in the West. Edited by Karin van Nieuwkerk. Austin: University of Texas Press, pp. ix-xii.

Kaji, Nobuyuki. 2018. Masukomi Gizensha Retsuden: Tatemae o Iitsunoru Hitobito [Biographies of Hypocrites in Mass-Communication: People Who Insist on Their Official Positions]. Tokyo: Asuka Shinsha.

Kanayama, Saho. 2011. Nihon de Tanoshiku Musurimu Kosodate o Suruniwa [How to Enjoy Muslim Parenthood in Japan]. In Isurāmu to Josei [Islam and Women]. Edited by Naoko Kawada. Tokyo: Kokushokankōkai, pp. 105-32.

Kawada, Naoko. 2004. Nihonjin Joseishinto ga Kataru Isurāmu An-nai [An Introduction to Islam by a Female Japanese Believer]. Tokyo: Tsukubanesha.

Kawada, Naoko, ed. 2011. Isurāmu to Josei [Islam and Women]. Tokyo: Kokusho Kankōkai.

Kishida, Shū, and Tōru Kotaki. 2002. Amerika no Seigibyō, Isuramu no Genribyō: Isshinkyō no Byōri o Yomitoku [America's Justice Illness and Islam's Fundamentalism Illness: An Analysis of the Pathology of Monotheisms]. Tokyo: Shunjūsha.

Komura, Akiko. 2015. Nihon to Isurāmu ga Deau Toki: Sono Rekishi to Kanōsei [When Japan Meets Islam: The History and Possibilities]. Tokyo: Gendai Shokan.

Kono, Shoichiro. 2017a. IS wa Isuramukyō to Gyakuno Koto o Shiteiru. Musurimuno Genjitsu in Japan-“IS" ga Unda Gokaino naka de [The Reality of Muslims in Japan-Living under the Impact of the Misunderstanding Caused by the "IS"]. Nippon.com. June 28. Available online: https://www.nippon.com/ja/features/c04001/ (accessed on 14 March 2019).

Kono, Shoichiro. 2017b. Nikaidate Shinchiku Mosuku ni Komeru Omoi [Hopes for a New Two-storied Mosque Building]. Musurimuno Genjitsu in Japan-“'IS" ga Unda Gokaino naka de [The Reality of Muslims in JapanLiving under the Impact of the Misunderstanding Caused by the "IS"]. Nippon.com. June 28. Available online: https://www.nippon.com/ja/features/c04002/ (accessed on 14 March 2019).

Kono, Shoichiro. 2017c. Watashiga Nihonjin ni Kōran o Kubaru Riyū [The Reason I Distribute [Copies of] the Qur'an to Japanese People]. Musurimuno Genjitsu in Japan- “IS" ga Unda Gokaino naka de [The Reality of Muslims in Japan-Living under the Impact of the Misunderstanding Caused by the "IS"]. Nippon.com. July 14. Available online: https://www.nippon.com/ja/features/c04003/ (accessed on 14 March 2019).

Kono, Shoichiro. 2017d. Nihonjin wa Min-na Ōmu desu ka [Are the Japanese All [Members of] Aum Shinrikyo?]. Musurimu no Genjitsu in Japan—“IS" ga Unda Gokaino naka de [The Reality of Muslims in Japan—Living under the Impact of the Misunderstanding Caused by the "IS"]. Nippon.com. July 14. Available online: https://www.nippon.com/ja/features/c04004/ (accessed on 14 March 2019). 
Kudo, Masako. 2007. Becoming the Other in One's Own Homeland? The Processes of Self-construction among Japanese Muslim Women. Japanese Review of Cultural Anthropology 8: 3-27.

Kudo, Masako. 2008. Ekkyō No Jinruigaku: Zainichi Pakisutanjin No Tsumatachi [Anthropology of Border Crossing: Wives of Pakistanis Living in Japan]. Tokyo: University of Tokyo Press.

Kudo, Masako. 2009. Kantōkogai kara Musurimu to shiteno Ibasho o Kizuku: Pakisutanjin Dansei to Nihonjin Josei no Kokusaikekkon no Jirei kara [Creating Muslim Space in the Surburbs of Tokyo and Beyond: Case Studies of Pakistani Men and Their Japanese Wives]. Bunkajunruigaku 74: 116-35.

Kudo, Masako. 2014. Constructing "Home” across National Boundaries: A Case of Pakistan-Japanese Marriage. In Migration in China and Asia: Experience and Policy. Edited by Jijiao Zhang and Howard Duncan. Dordrecht: Springer, pp. 103-11.

Kunifuda, Hideyuki. 2017. Musurimu to Kekkonshite Kaishushita Joseitachi [Women who Converted upon Marrying a Muslim. 'Musurimuno Genjitsu in Japan-“IS" ga Unda Gokaino naka de [The Reality of Muslims in Japan—Living under the Impact of the Misunderstanding Caused by the "IS"]'. Nippon.com. September 6. Available online: https://www.nippon.com/ja/features/c04005/ (accessed on 14 March 2019).

Mainichi Shimbun. 2015. Nagoya Mosuku: Kyohaku, Iyagarase, “Gotōsan Hitojichi” de Aitsugu [Nagoya Mosque: Threats and Harassments Come in One after Another after Mr. Goto was Taken Hostage]. February 25.

Mainichi Shimbun. 2016. Isuramukyō ni Kaishū, Joseitachi no Kurashi, Jiseidai no tame "Ikiyasusa" o [Lives of Female Converts to Islam, Working to Make Life Easier for the Next Generation]. May 22. Available online: https://mainichi.jp/articles/20160322/ddn/013/040/028000c (accessed on 16 July 2019).

Matsumoto, Taka'aki. 2006. Nihon no Kōkōsei ga Idaku Isurāmuzō to sono Zesei ni Muketa Torikumi [Images of Islam by Japanese Nigh School Students and Attempts to Correct them]. Annals of Japan Association for Middle East Studies 21: 193-214.

Matsuyama, Yohei, and Tomoko Matsuyama. 2011. Nihonjin Musurimu Fūfu to Nihonshakai [Japanese Muslim Couples and Japanese Society]. In Isurāmu to Josei [Islam and Women]. Edited by Naoko Kawada. Tokyo: Kokusho Kankōkai, pp. 77-103.

Minesaki, Hiroko. 2015. Isurāmufukkō to Jendā: Gendai Ejiputo o Ikiru Joseitachi [Islamic Revival and Gender: Women Living in Contemporary Egypt]. Kyoto: Shōwadō.

Miura, Toru. 2006. Perceptions of Islam and Muslims in Japanese High Schools: Questionnaire Survey and Textbooks. Annals of Japan Association for Middle East Studies 21: 173-91.

Mullins, Mark R. 2005. Meido-in-japan no Kirisutokyō [Christianity Made in Japan: A Study of Indigenous Movements]. Translated by Takasaki Megumi. Tokyo: Transview.

Nakata, Ko. 2015. Naze Watashi wa Isurāmukyōto ni Natta no ka [Why I Became a Muslim]. Tokyo: Ōta Shuppan.

NHK Educational TV. 2016. Chanto Shiritai! Isuramukyōto Hogoshāzu Tōjō [We Want to Know Properly! Here Come Muslim Parents]. In Uwasa no Hogoshakai [Well-known Meetings of Parents]. July 15. Available online: https://mainichi.jp/articles/20160322/ddn/013/040/028000c (accessed on 16 July 2019).

Numajiri, Masayuki. 2017. Gendainihon ni okeru "Harāru" o meguru Shomondai [Issues Concerning "Halal" in Contemporary Japan]. In Ikyō no Nyūkamātachi: Nihon ni okeru Imin to Shūkyō [Newcomers with Foreign Religions: Migration and Religion in Japan]. Edited by Hizuru Miki. Tokyo: Shinwasha, pp. 65-93.

Obuse, Kieko. 2011. Doctrinal Accommodations in Buddhist-Muslim Relations with Special Reference to Contemporary Japan. Ph.D. dissertation, University of Oxford, Oxford, UK.

Obuse, Kieko. 2015. Islam in Japan. In Oxford Bibliographies in Islamic Studies. Edited by Andres Rippin. New York: Oxford University Press, Available online: http://www.oxfordbibliographies.com/view/document/obo9780195390155/obo-9780195390155-0167.xml (accessed on 15 March 2019).

Obuse, Kieko. 2017. The Japan Islamic Congress: A Possible Case of an Islamic New Religion in Japan. Journal of Religion in Japan 6: 241-63. [CrossRef]

Obuse, Kieko. Forthcoming. Towards a Japanese Islam: A Japanese Convert's Attempt of Indigenisation. In Muslim Minorities in East Asia: Accommodation and Contestation in the Lived Experience of East Asian Muslims. Edited by Yuka Kobayashi. Amsterdam: Amsterdam University Press.

Okai, Hirofumi. 2018. Nihon to Isurāmu: Mosuku kara Miru Nihon no Musurimu Komyuniti [Japan and Islam: Muslim Communities Seen through Mosques]. In Daigakusei, Shakaijin no tame no Isurāmukōza. Edited by Yasushi Kosugi, Kenji Kuroda and Tatsuro Futatsuyama. Kyoto: Nakanishiya Shuppan, pp. 22-38.

Özyürek, Esra. 2015. Being German Becoming Muslim: Race, Religion and Conversion in the New Europe. Princeton and Oxford: Princeton University Press. 
Paramore, Kiri. 2009. Ideology and Christianity in Japan. London and New York: Routledge.

Park, Robert E. 1928. Human Migration and the Marginal Man. American Journal of Sociology 33: 881-93. [CrossRef] Penn, Michael. 2008. Public Faces and Private Spaces: Islam in the Japanese Context. Asia Policy 5: 89-104. [CrossRef] Rambo, Lewis R. 1993. Understanding Religious Conversion. New Haven and London: Yale University Press.

Roald, Anne Sofie. 2004. New Muslims in the European Context: The Experience of Scandinavian Converts. Leiden: Brill. Roald, Anne Sofie. 2006. The Shaping of a Scandinavian "Islam": Converts and Gender Equal Opportunity. In Women Embracing Islam: Gender and Conversion in the West. Edited by Karin van Nieuwkerk. Austin: University of Texas Press, pp. 48-70.

Roald, Anne Sofie. 2012. The Conversion Process in Stages: New Muslims in the Twenty-First Century. Islam and Christian-Muslim Relations 23: 347-62. [CrossRef]

Sadakata, Akira. 2005. Zō-o no Shūkyō: Yudaya, Kirisuto Isuramukyō to Seinaru Zō-o [Religions of Hatred: Judaism, Christianity, Islam and Sacred Hatred]. Tokyo: Yōsensha.

Sakurai, Keiko. 2003. Nihon no Musurimu Shakai [Japan's Muslim Communities]. Tokyo: Chimuka Shobō.

Sakurai, Keiko. 2008. Muslims in Contemporary Japan. Asia Policy 5: 69-87. [CrossRef]

Sato, Ken-ei. 2010a. Nihon de Kurasu Musurimu no Ko [Muslim Children in Japan]. Nikkei Kids Plus, 83-89.

Sato, Ken-ei. 2010b. Musurimu no Kodomotachi [Muslim Children]. Shūkan Kin-yōbi, 37-39.

Sato, Ken-ei. 2015. Nihon no naka de Isuramukyō o Shinjiru [Embracing Islam in Japan]. Tokyo: Bungei Shunjū.

Sugita, Hideaki. 1995. Nihonjin no Chūtō Hakken [The Japanese Discovery of the Middle East]. Tokyo: University of Tokyo Press.

Suzuki, Hiroshi. 2002. Isurāmukyōto no İbun [What a Muslim Has to Say]. Tokyo: Mekon.

Suzuki, Hiroshi. 2004. Isurāmu no Jōshiki ga Wakaru Shōjiten [A Little Encyclopedia of Common Knowledge about Islam]. Tokyo: PHP.

Takahashi, Saul J. 2018. Muslim Surveillance in Japan: A Narrative Aimed at Trivialization. Islamophobia Studies Journal 4: 195-209. [CrossRef]

Takeshita, Shuko. 2001. Nihojinzuma no Isurāmu eno Taiō: Gaikokujin Musurimu o Otto ni Motsu Tsuma no Jitsureibunseki kara [Japanese Wives' Adaptations to Islam: An Analysis of Cases of Wives Who Have Foreign Husbands]. The Journal of Aichi Gakuin University Humanities E Sciences 3: 157-72.

Tanada, Hirofumi. 2015. Nihon no Mosuku: Tainichi Muslim no Shakiteki Katsudō [Mosques in Japan: Social Activities of Muslims Living in Japan]. Tokyo: Yamakawa Shuppansha.

Terada, Kimiyo. 2003. Kyōseishakai to Mainoriti eno Shien: Nihonjin Musurima no Syakiteki Taīo kara [A Convivial Society and Support of Minorities: Social Adaptations of Japanese Muslim Women]. Tokyo: Tōshindō.

Umehara, Takeshi. 2002. Umehara Takeshi no Jugyō: Bukkyō [Lessons with Takeshi Umehara: Buddhism]. Tokyo: Asahi Shinbunsha.

van Es, Margaretha A. 2018. Muslims Denouncing Violent Extremism: Competing Essentialisms of Islam in Dutch Public Debate. Journal of Muslims in Europe 7: 146-66. [CrossRef]

van Es, Margaretha A. 2019a. Muslim Women as 'Ambassadors' of Islam: Breaking Stereotypes in Everyday Life. Identities: Global Studies in Culture and Power 26: 375-92. [CrossRef]

van Es, Margaretha A. 2019b. The Promise of the Social Contract: Muslim Perspectives on the Culturalization of Citizenship and the Demand to Denounce Violent Extremism. Ethnic and Racial Studies 42: 141-58. [CrossRef]

van Nieuwkerk, Karin. 2006. Gender and Conversion to Islam in the West. In Women Embracing Islam: Gender and Conversion in the West. Edited by Karin van Nieuwkerk. Austin: University of Texas Press, pp. 1-16.

Yagi, Kumiko. 2015. Jihibukaki Kami no Shokutaku: Isuramu o "Shoku" kara Miru [Tables of Merciful God: A Look at Islam through Eating]. Tokyo: University of Tokyo Press.

Yamaguchi, Kazuomi. 2018. Nihon de Umaresodatta Musume to "Musurimu no Chichi" [A Daughter Born and Brought up in Japan and a "Muslim Father"]. Musurimu no Genjitsu in Japan-“'IS" ga Unda Gokaino naka de [The Reality of Muslims in Japan—Living under the Impact of the Misunderstanding Caused by the "IS"]. Nippon.com. March 26. Available online: https://www.nippon.com/ja/features/c04006/?pnum=1 (accessed on 14 March 2019). 
Yasuda, Yoshinori. 2006. Isshinkyō no Yami: Animizumu no Fukken [The Darkness of Monotheism: Restoring the Power of Animism]. Tokyo: Chikuma Shobō.

Yoro, Takeshi. 2003. Baka no Kabe [The Wall of Stupidity]. Tokyo: Shinchōsha.

Zebiri, Kate. 2008. British Muslim Converts: Choosing Alternative Lives. Oxford: Oneworld.

(C) 2019 by the author. Licensee MDPI, Basel, Switzerland. This article is an open access article distributed under the terms and conditions of the Creative Commons Attribution (CC BY) license (http://creativecommons.org/licenses/by/4.0/). 